\title{
Malignant hepatic epithelioid angiomyolipoma with recurrence in the lung 7 years after hepatectomy: a case report and literature review
}

\author{
Yasunari Fukuda ${ }^{1,8^{*}}$, Hideyasu Omiya ${ }^{1}$, Koji Takami ${ }^{1}$, Kiyoshi Mori ${ }^{2}$, Yoshinori Kodama ${ }^{2}$, Masayuki Mano², \\ Yoriko Nomura ${ }^{3}$, Jun Akiba ${ }^{4}$, Hirohisa Yano ${ }^{4}$, Osamu Nakashima ${ }^{5}$, Mitsumasa Ogawara ${ }^{6}$, Eiji Mita ${ }^{7}$, \\ Shoji Nakamori ${ }^{1}$ and Mitsugu Sekimoto ${ }^{1}$
}

\begin{abstract}
Angiomyolipoma (AML) arising in the liver is rare and usually benign, but it occasionally has malignant potential. A 58-year-old man with a liver tumor identified by a previous doctor with features suggestive of hepatocellular carcinoma on computed tomography (CT) underwent anterior segmentectomy of the liver in 2006. Microscopically, the tumor was composed of exclusively epithelioid cells that were scatteredly positive for human melanoma black 45 on immunohistochemistry. Accordingly, primary hepatic epithelioid AML (eAML) was diagnosed. The patient was subsequently referred to our hospital for follow-up after hepatectomy. He had event-free survival for nearly 7 years. In 2013, two well-defined round nodules were detected in the right lung field by chest $C T$, and partial pneumonectomy was performed for diagnosis and treatment. Histological examination of the resected lung tissue showed that it was morphologically and immunohistochemically identical to his primary hepatic eAML, leading to the diagnosis of pulmonary metastasis. This paper demonstrates a rare case of malignant hepatic eAML with late recurrence in the lung after hepatectomy.
\end{abstract}

Keywords: Hepatic angiomyolipoma, Perivascular epithelioid cell, Malignant potential

\section{Background}

Angiomyolipoma (AML) is a relatively rare mesenchymal tumor. Histologically, it is composed of blood vessels, adipose tissue, and smooth muscle. AML is most commonly observed in the kidney, followed by the liver. The tumor is thought to originate from pluripotent perivascular epithelioid cells (PECs), although its normal tissue counterpart remains unclear $[1,2]$. PEC is immunopositive for melanocytic and myogenic markers [3]. In addition, a group of tumors formed by PEC proliferation has been recognized as PEComas, firstly described by Bonetti and colleagues

\footnotetext{
* Correspondence: yfukuda@gesurg.med.osaka-u.ac.jp

${ }^{1}$ Department of Surgery, National Hospital Organization Osaka National Hospital, Osaka, Japan

${ }^{8}$ Department of Gastroenterological Surgery, Osaka University Graduate

School of Medicine, 2-2 Yamadaoka, Suita, 565-5111 Osaka, Japan

Full list of author information is available at the end of the article
}

in 1992 [1] and currently recognized by the World Health Organization [4]. AML is considered a member of the PEComa family [4]. AML can be histologically classified according to the ratio of the three heterogeneous components, from the classic triphasic type to a monotypic type [5]. Among the monotypic types of AML, epithelioid AML (eAML) is predominantly composed of epithelioid cells and does not contain blood vessels or adipose tissue. Although in general AML has good biological behavior, it can have malignant potential with distant metastasis, recurrence, and associated mortality [6-15]. We describe a case of malignant hepatic eAML that recurred in the lung nearly 7 years after hepatectomy for the initial tumor and review the characteristics of malignant hepatic AML with recurrence. 


\section{Case presentation}

A 58-year-old man was incidentally found to have a liver tumor measuring $20 \mathrm{~mm}$ by abdominal ultrasonography during a routine company health examination in 2004. The tumor grew in size over the next 2 years, and closer inspections were conducted by a previous physician in 2006. Enhanced computed tomography (CT) of the abdomen showed a 70- $\mathrm{mm}$ mass with hemorrhagic and necrotic changes in the right lobe of the liver (segment 5), with early arterial phase staining and late phase washout, which seemed to be consistent with hepatocellular carcinoma (HCC) (Fig. 1). Anterior segmentectomy of the liver was performed. Macroscopically, non-encapsulated tumor had irregular borders. Sectioning of resected specimen revealed a white to yellow, friable, hemorrhagic mass measuring $63 \times 50 \mathrm{~mm}$ (Fig. 2). Microscopically, hematoxylin and eosin staining showed atypical epithelioid cells containing abundant clear to eosinophilic granular cytoplasm arranged in nests and sheets. The cells were unevenly distributed and had pleomorphic nuclei of varying sizes. Blood vessels were inconspicuous and mature adipose tissue was not detected. Both bile ducts and portal tracts were involved in the tumor. Immunohistochemically, the tumor cells were negative for hepatocyte paraffin 1 (HepPar 1) and alpha fetoprotein. In contrast, the tumor cells were scatteredly positive for melanocytic markers including human melanoma black 45 (HMB-45) and Melan A, but negative for smooth muscle antigen (SMA) and S100 protein, together with negative for c-kit and moderately high Ki-67 labeling index (12.9 \%) (Fig. 3).
Accordingly, primary hepatic eAML was diagnosed at that time.

After hepatectomy, the patient was referred to our hospital and followed every 6 months on an outpatient basis. No hepatic recurrence was observed over nearly 7 years. In 2013, a chest X-ray showed a well-defined nodule in the right lung field (Fig. 4a). Chest CT showed two round nodules in segments 1 and 3 of the right lung, measuring 10 and $4 \mathrm{~mm}$, respectively (Fig. 4b, c). Fluorodeoxyglucose-positron emission tomography did not show any uptake. Since the diagnosis could not be confirmed by inspection through bronchoscopy, partial pneumonectomy was performed for diagnostic and therapeutic purposes. Macroscopically, the two resected specimens included solid white masses. Microscopically, the neoplastic cells were morphologically similar to those of the primary hepatic tumor. There was no evidence of vascular invasion. Immunohistochemically, the tumor cells were diffusely positive for HMB-45 and negative for SMA and S-100 protein. In addition, the tumor cells were negative for c-kit and the Ki-67 labeling index was $9.0 \%$ (Fig. 5). Therefore, a diagnosis of lung metastases from hepatic eAML was made. Loss of tuberous sclerosis complex (TSC) genes, TSC1 and TSC2, was not detected. The patient has remained recurrence-free on a closer follow-up schedule for 2 years after pneumonectomy.

\section{Discussion}

Since it was first described by Ishak [16] in 1976, hepatic AML is now a well-recognized tumor. The

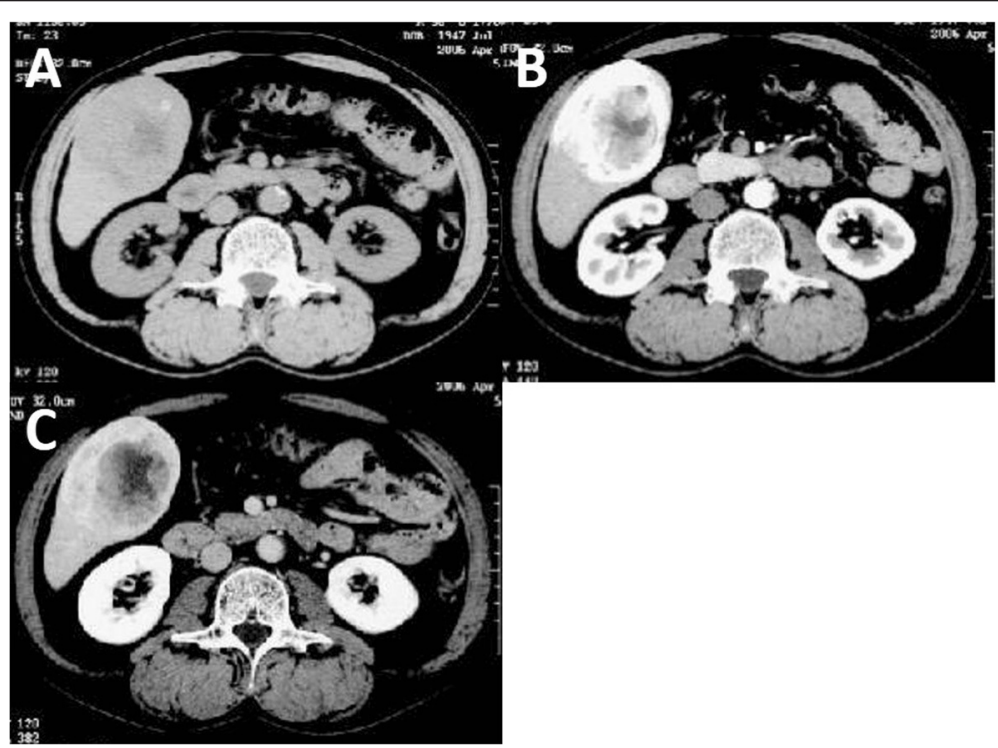

Fig. 1 Imaging of primary hepatic AML. a Plain CT showed a low-density mass in segment 5 of the liver. b, c Enhanced CT showed a tumor with hemorrhagic and necrotic changes, with early arterial phase staining and late phase washout 


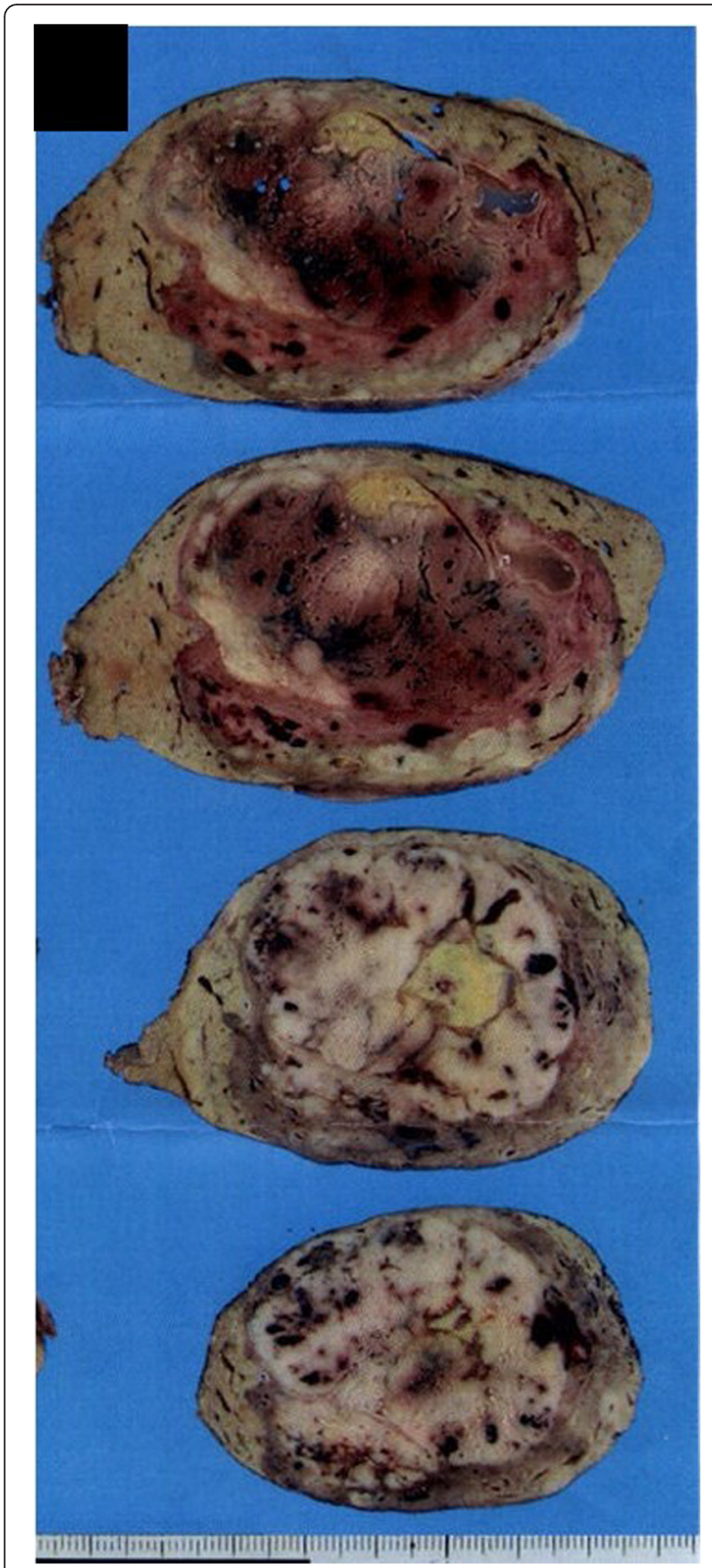

Fig. 2 Sections of the resected hepatic AML specimen. The tumor included a white to yellow solid mass with areas of hemorrhage

number of reports on hepatic AML, including malignant cases, has continued to increase worldwide. In recent years, the clinicopathological characteristics of malignant hepatic AML have been intensively investigated despite many challenges. Tumor size has been reported as a simple and clear predictor of malignant AML $[10-14,17]$. Although the cutoff value varies in the literature, Ding and colleagues [14] identified that tumors greater than $60 \mathrm{~mm}$ in diameter might have malignant potential and this was true of our case $(63 \mathrm{~mm})$. In terms of histology, cytologic atypia, pleomorphism, necrosis, and high mitotic rate were reported as predictors of malignant potential [10, 11, 13, 17]. The presence of cytologic atypia and necrosis are frequently observed in malignant cases, including ours. However, Nonomura and colleagues [5] demonstrated that atypia and pleomorphism are occasionally found in epithelioid cells and does not always indicate malignant hepatic AML. In addition, the monotypic epithelioid variant of AML arising from the kidney had been regarded as having malignant potential [18, 19], whereas data on those of hepatic origin are scarce. Recently, the number of reports on malignant classical AML in the liver has also been increasing $[10,12,13,15]$. Accumulation of cases is necessary to clarify the histological differences between malignant and benign AML.

Immunohistochemically, there was a difference in the degree of staining for HMB- 45 between primary and metastatic lesion. Considering intratumoral heterogeneity has been observed in various malignancies [20], this difference may suggest malignant potential in our case. Moreover, a previous investigation showed that lack of c-kit expression is suggestive of malignant hepatic AML, [13] in contrast to c-kit immunopositivity in benign lesions [21]. Indeed, in four cases where c-kit expression was evaluated, all were negative or weakly positive. Although further investigation of the intensity of c-kit staining in malignant cases is required, it is potentially a predictive marker.

There is a paucity of detailed data on the metastasis or recurrence pattern of malignant hepatic AML. As summarized in Table 1, the most frequently observed site of recurrence is the liver (nine cases), followed by the lung (three cases), pancreas (two cases), and other organs, indicating a hematogenous pattern of metastasis for malignant hepatic AML. Furthermore, our case showed that the lung could be the first site of recurrence for malignant hepatic AML. Thus, prudent evaluation of the lung fields by chest X-ray or chest $\mathrm{CT}$ in addition to following the residual liver should be conducted.

Four patients died due to disease recurrence, indicating an unfavorable prognosis after recurrence $[10,12-14]$. In a case described by Dalle and colleagues [7], the tumor was observed for 5 years before it was resected, and multiple metastases appeared in the residual liver just 5 months after resection. Moreover, median recurrence-free survival of the ten patients with recurrence was 36 months (range, 5108 months); three patients relapsed more than 


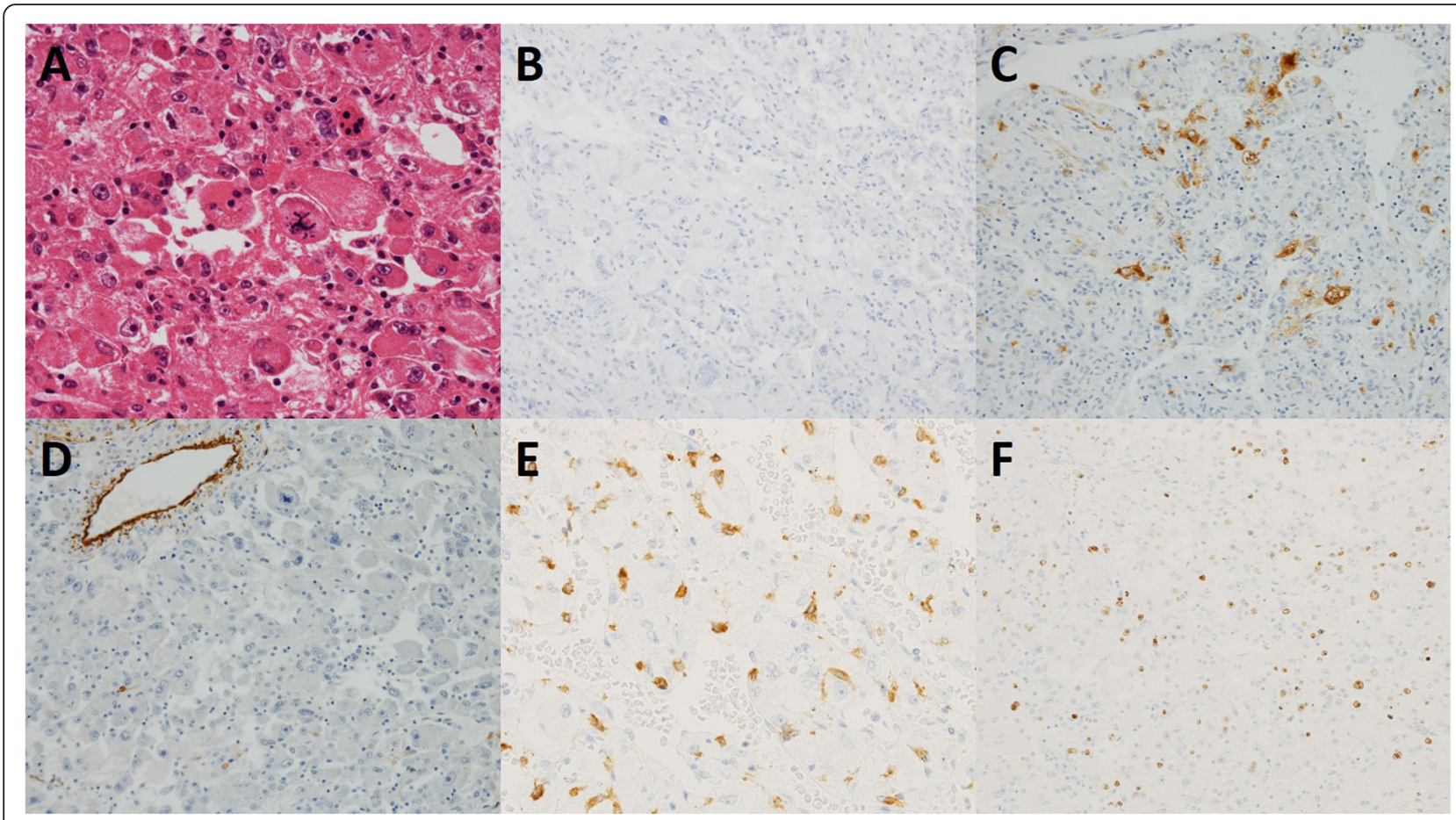

Fig. 3 Pathological findings of hepatic AML. a Hematoxylin and eosin staining showed atypical epithelioid cells containing clear to eosinophilic granular cytoplasm and pleomorphic nuclei (original magnification $\times 400$ ). b Immunohistochemical staining was negative for HepPar 1 (original magnification ×200), c scatteredly positive for HMB-45 (original magnification ×200), d inconspicuous for SMA (original magnification ×200), and e negative for c-kit (mast cells were expressing c-kit; original magnification $\times 400$ ). f The Ki-67 labeling index was $12.9 \%$ (original magnification $\times 200$ )

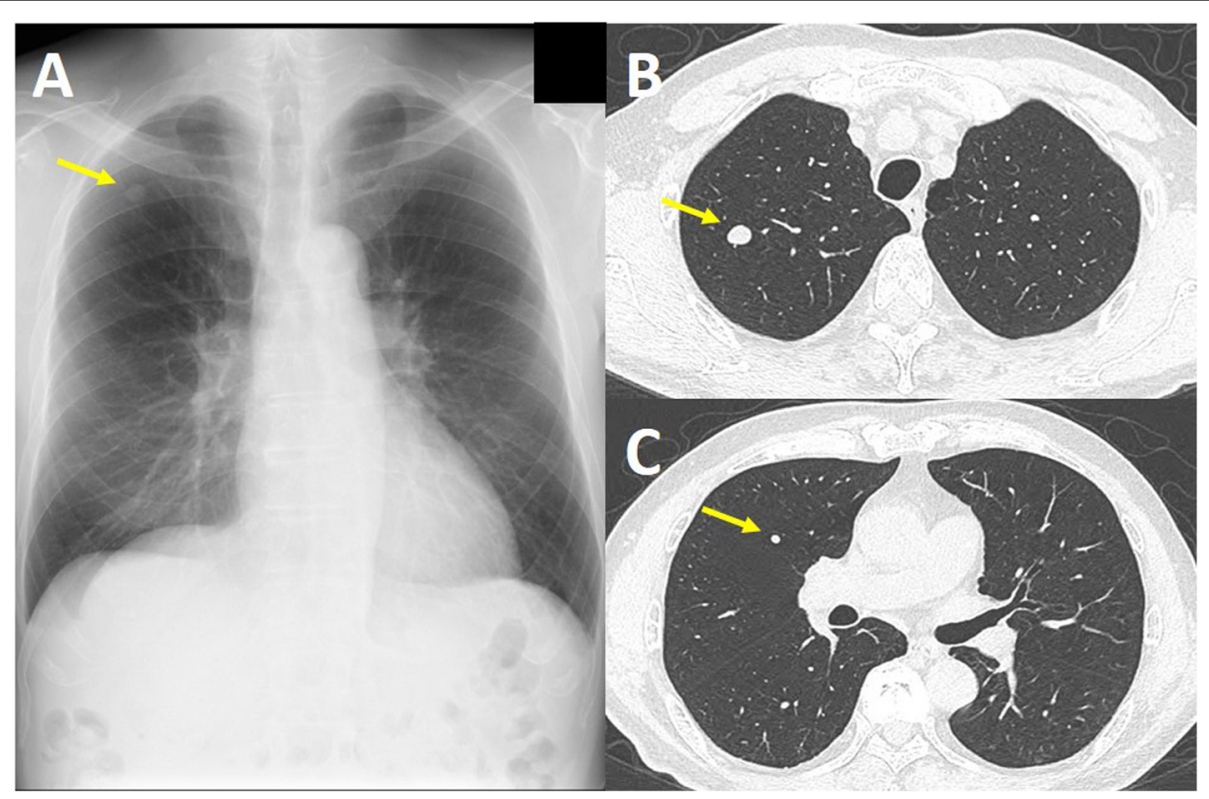

Fig. 4 Imaging of the recurrent lesions in the lung. a Chest X-ray demonstrated a well-defined nodule in the right upper lung field (arrow). b, c Chest CT demonstrated two round nodules in segments 1 and 3 of the right lung, respectively (arrow) 


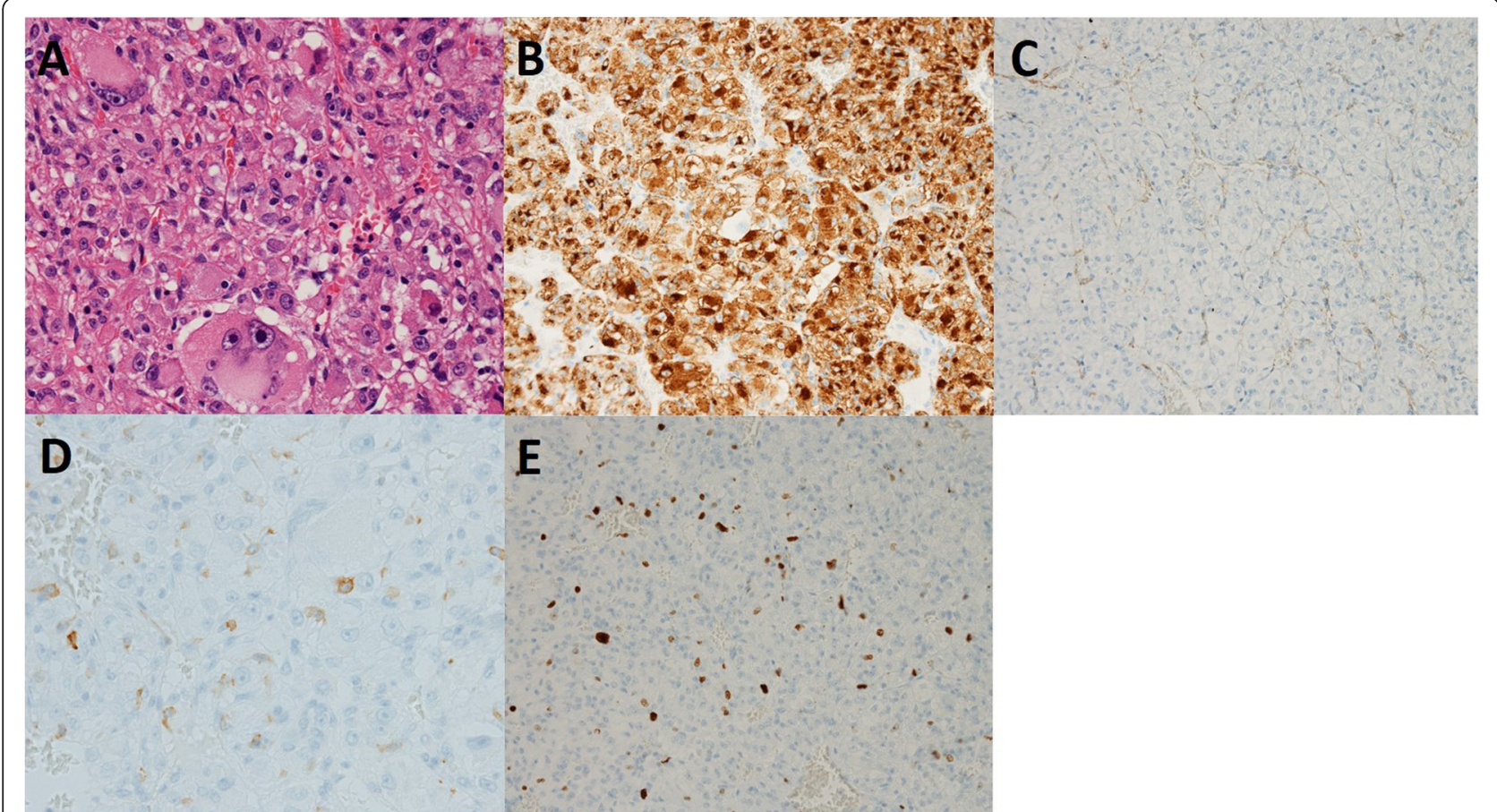

Fig. 5 Pathological findings of the recurrent lesions in the lung. a Hematoxylin and eosin staining showed that the tumor cells were morphologically similar to those of the primary hepatic AML tumor (original magnification $\times 400$ ). $\mathbf{b}$ Immunohistochemical staining was diffusely positive for HMB45 (original magnification $\times 200$ ), $\mathbf{c}$ negative for SMA (original magnification $\times 200$ ), and $\mathbf{d}$ negative for c-kit (original magnification $\times 400$ ). e The Ki-67 labeling index was $9.0 \%$ (original magnification $\times 200$ )

5 years after initial resection. Prompt surgical treatment and careful follow-up for a long period is crucial to increasing the survival of patients with malignant disease. In addition, our case suggests that early detection and re-resection of the site of recurrence could improve the prognosis of patients with malignant case.

\section{Conclusions}

In conclusion, we reported a case of malignant hepatic AML with late recurrence in the lung and examined the characteristics of recurrence in patients with malignant hepatic AML. The prognosis of patients with malignant hepatic AML is poor. In this respect, we regard hepatic AML as a borderline malignant tumor, and aggressive therapeutic intervention is recommended since surgical resection is indisputably the most reliable curative treatment.

\section{Consent}

Written informed consent was obtained from the patient for publication of this case report and any accompanying images. A copy of the written consent is available for review by the Editor-in-Chief of this journal.

\section{Abbreviations}

AML: angiomyolipoma; CT: computed tomography; eAML: epithelioid AML; HCC: hepatocellular carcinoma; HepPar 1: hepatocyte paraffin 1; HMB45: human melanoma black 45; PEC: perivascular epithelioid cell; SMA: smooth muscle antigen; TSC: tuberous sclerosis complex.

\section{Competing interests}

The authors declare that they have no competing interests.

\section{Authors' contributions}

YF drafted the manuscript. YF, HO, and KT were the patient's attending physicians and performed the resection of the pulmonary lesions. $\mathrm{MO}$ and EM followed the patient in the outpatient clinic. SN and MS were the supervising surgical oncologists. YN, JA, HY, and ON participated in the pathological examination of the primary hepatic eAML, and $\mathrm{KM}$, YK, and $\mathrm{MM}$ participated in the pathological examination of the pulmonary lesions. All authors read and approved the final manuscript.

\section{Author details}

${ }^{1}$ Department of Surgery, National Hospital Organization Osaka National Hospital, Osaka, Japan. ${ }^{2}$ Department of Pathology, National Hospital Organization Osaka National Hospital, Osaka, Japan. ${ }^{3}$ Department of Gastroenterological Surgery, Kurume University School of Medicine, Kurume, Japan. ${ }^{4}$ Department of Pathology, Kurume University School of Medicine, Kurume, Japan. ${ }^{5}$ Department of Clinical Laboratory Medicine, Kurume University Hospital, Kurume, Japan. ${ }^{6}$ Department of Respiratory Medicine, National Hospital Organization Osaka National Hospital, Osaka, Japan. ${ }^{7}$ Department of Gastroenterology and Hepatology, National Hospital Organization Osaka National Hospital, Osaka, Japan. ${ }^{8}$ Department of Gastroenterological Surgery, Osaka University Graduate School of Medicine, 2-2 Yamadaoka, Suita, 565-5111 Osaka, Japan. 
Table 1 Previous reports of malignant hepatic AML with recurrence

\begin{tabular}{|c|c|c|c|c|c|c|c|c|c|c|c|c|c|c|}
\hline Case & Reference & Age & Gender & $\begin{array}{l}\text { Size } \\
(\mathrm{cm})\end{array}$ & $\begin{array}{l}\text { Resection } \\
\text { for primary }\end{array}$ & Histology & $\begin{array}{l}\text { Cytologic } \\
\text { atypia }\end{array}$ & Necrosis & Ki-67 & c-kit & Recurrence site & $\begin{array}{l}\text { RFS } \\
\text { (months) }\end{array}$ & $\begin{array}{l}\text { Resection for } \\
\text { recurrence }\end{array}$ & Prognosis \\
\hline 1 & [7] & 70 & $\mathrm{~F}$ & 15 & + & $\begin{array}{l}\text { Epithelioid } \\
\text { variant }\end{array}$ & + & + & N/A & N/A & Liver & 5 & - & $\begin{array}{l}\text { Alive with the disease details } \\
\text { were not shown }\end{array}$ \\
\hline 2 & [8] & 16 & $\mathrm{~F}$ & 12 & + & $\begin{array}{l}\text { Epithelioid } \\
\text { variant }\end{array}$ & + & N/A & N/A & N/A & Liver & 6 & + & N/A \\
\hline 3 & [9] & 51 & $\mathrm{~F}$ & 10 & + & $\begin{array}{l}\text { Epithelioid } \\
\text { variant }\end{array}$ & N/A & N/A & $2 \%$ & N/A & Liver & 36 & + & $\begin{array}{l}\text { Alive without the disease } \\
1.5 \text { years after recurrence }\end{array}$ \\
\hline 4 & [10] & 30 & M & 18 & + & $\begin{array}{l}\text { Classical } \\
\text { AML }\end{array}$ & + & + & $30 \%$ & $\begin{array}{l}\text { Weakly } \\
+\end{array}$ & Liver, pancreas, and lung & 36 & + & $\begin{array}{l}\text { Died } 4 \text { months after } \\
\text { recurrence }\end{array}$ \\
\hline 5 & [11] & 60 & $\mathrm{~F}$ & 14 & + & $\begin{array}{l}\text { Epithelioid } \\
\text { variant }\end{array}$ & - & - & N/A & $\begin{array}{l}\text { Weakly } \\
+\end{array}$ & $\begin{array}{l}\text { Liver, trapezius muscle, } \\
\text { bladder, lung, and pancreas }\end{array}$ & 108 & + & $\begin{array}{l}\text { Alive with the disease details } \\
\text { were not shown }\end{array}$ \\
\hline 6 & [12] & 37 & $\mathrm{~F}$ & 13 & + & $\begin{array}{l}\text { Classical } \\
\text { AML }\end{array}$ & + & N/A & N/A & N/A & Liver, lung & 6 & - & $\begin{array}{l}\text { Died } 8 \text { months after } \\
\text { recurrence }\end{array}$ \\
\hline 7 & [13] & 43 & $\mathrm{~F}$ & 11 & + & $\begin{array}{l}\text { Classical } \\
\text { AML }\end{array}$ & + & + & Weak & - & $\begin{array}{l}\text { Liver, peritonium, } \\
\text { retroperitonium, and } \\
\text { omentum }\end{array}$ & 6 & - & $\begin{array}{l}\text { Died } 3 \text { months after } \\
\text { recurrence }\end{array}$ \\
\hline 8 & [14] & 31 & $\mathrm{~F}$ & 8 & + & N/A & N/A & N/A & N/A & N/A & Liver & 72 & - & Died 1 year after recurrence \\
\hline 9 & [15] & 37 & $\mathrm{~F}$ & 9 & + & $\begin{array}{l}\text { Classical } \\
\text { AML }\end{array}$ & + & + & $4 \%$ & N/A & Liver & 36 & $\begin{array}{l}+ \\
\text { (transplantation) }\end{array}$ & $\begin{array}{l}\text { Alive without the disease } \\
\text { details were not shown }\end{array}$ \\
\hline $\begin{array}{l}\text { Present } \\
\text { case }\end{array}$ & & 58 & M & 6.3 & + & $\begin{array}{l}\text { Epithelioid } \\
\text { variant }\end{array}$ & + & + & $13 \%$ & $\begin{array}{l}\text { Weakly } \\
+\end{array}$ & Lung & 84 & + & $\begin{array}{l}\text { Alive without the disease } \\
2 \text { years after recurrence }\end{array}$ \\
\hline
\end{tabular}


Received: 11 December 2015 Accepted: 29 March 2016

Published online: 02 April 2016

\section{References}

1. Bonetti F, Pea M, Martignoni G, Zamboni G. PEC and sugar. Am J Surg Pathol. 1992;16:307-8.

2. Martignoni G, Pea M, Reghellin D, Zamboni G, Bonetti F. PEComas: the past, the present and the future. Virchows Arch. 2008;452:119-32.

3. Makhlouf HR, Ishak KG, Shekar R, Sesterhenn IA, Young DY, Fanburg-Smith JC. Melanoma markers in angiomyolipoma of the liver and kidney: a comparative study. Arch Pathol Lab Med. 2002;126:49-55.

4. Fletcher CDM, Unni KK, Mertens F. World Health Organization classification of tumors. Pathology and genetics of soft tissue and bone. Lyon: IARC Press; 2002. p. 221-2.

5. Nonomura A, Mizukami Y, Kadoya M, Matsui O, Shimizu K, Izumi R. Angiomyolioma of the liver: its clinical and pathological diversity. J Hep Pancr Surg. 1996;3:122-32.

6. Ohmori T, Arita N, Uraga N, Tabei R, Yamamoto M, Takaoka M, et al. Giant hepatic angiomyolipoma. Histopathology. 1989;15:540-3.

7. Dalle I, Sciot R, de Vos R, Aerts R, van Damme B, Desmet V, et al. Malignant angiomyolipoma of the liver: a hitherto unreported variant. Histopathology. 2000:36:443-50.

8. Croquet V, Pilette C, Aube C, Bouju B, Oberti F, Cervi C, et al. Late recurrence of a hepatic angiomyolipoma. Eur J Gastroenterol Hepatol. 2000; 12:579-82.

9. Flemming $P$, Lehmann U, Becker T, Klempnauer J, Kreipe H. Common and epithelioid variants of hepatic angiomyolipoma exhibit clonal growth and share a distinctive immunophenotype. Hepatology. 2000;32:213-7.

10. Deng YF, Lin Q, Zhang SH, Ling YM, He JK, Chen XF. Malignant angiomyolipoma in the liver: a case report with pathological and molecular analysis. Pathol Res Pract. 2008;204:911-8.

11. Parfitt JR, Bella AJ, Izawa JI, Wehrli BM. Malignant neoplasm of perivascular epithelioid cells of the liver. Arch Pathol Lab Med. 2006;130:1219-22.

12. Yang $\mathrm{CY}, \mathrm{Ho}$ MC, Jeng $\mathrm{YM}, \mathrm{Hu}$ RH, Wu YM, Lee PH. Management of hepatic angiomyolipoma. J Gastrointest Surg. 2007;11:452-7.

13. Nguyen TT, Gorman B, Shields D, Goodman Z. Malignant hepatic angiomyolipoma: report of a case and review of literature. Am J Surg Pathol. 2008;32:793-8.

14. Ding GH, Liu Y, Wu MC, Yang GS, Yang JM, Cong WM. Diagnosis and treatment of hepatic angiomyolipoma. J Surg Oncol. 2011;103:807-12.

15. Wang WT, Li ZQ, Zhang GH, Guo Y, Teng MJ. Liver transplantation for recurrent posthepatectomy malignant hepatic angiomyolipoma: a case report. World J Gastroenterol. 2015;21:3755-8.

16. Ishak KG. Mesenchymal tumors of the liver. In: Okuda K, Peters RL, editors. Hepatocellular carcinoma. New York: John Wiley and Sons; 1976. p. 247-307.

17. Folpe AL, Kwiatkowski DJ. Perivascular epithelioid cell neoplasms: pathology and pathogenesis. Hum Pathol. 2010;41:1-15.

18. Martignoni G, Pea M, Bonetti F, Zamboni G, Carbonara C, Longa L, et al. Carcinomalike monotypic epithelioid angiomyolipoma in patients without evidence of tuberous sclerosis: a clinicopathologic and genetic study. Am J Surg Pathol. 1998;22:663-72.

19. Pea M, Bonetti F, Martignoni G, Henske EP, Manfrin E, Colato C, et al. Apparent renal cell carcinomas in tuberous sclerosis are heterogeneous: the identification of malignant epithelioid angiomyolipoma. Am J Surg Pathol. 1998;22:180-7.

20. Shackleton M, Quintana E, Fearon ER, Morrison SJ. Heterogeneity in cancer: cancer stem cells versus clonal evolution. Cell. 2009;138:822-9.

21. Makhlouf HR, Remotti HE, Ishak KG. Expression of KIT (CD117) in angiomyolipoma. Am J Surg Pathol. 2002;26:493-7.

\section{Submit your manuscript to a SpringerOpen ${ }^{\circ}$} journal and benefit from:

- Convenient online submission

- Rigorous peer review

- Immediate publication on acceptance

- Open access: articles freely available online

- High visibility within the field

- Retaining the copyright to your article

Submit your next manuscript at $>$ springeropen.com 